\title{
Out of Place: Space as Trope in Recent Argentine Theatre
}

\author{
Sharon Magnarelli
}

There is no single way to produce a play or performance text, and each production constructs new meanings, reveals new things, creates a new entity.

Gay McAuley 233

Any group that endeavors to perform a written text surely begins by confronting the inevitable power of that text. In the process of the performance, however, that initial text is often overpowered, infiltrated or dispossessed by the performance itself (Heuvel 5). ${ }^{1}$ As a result, any performance we see necessarily affects forever, for better or for worse, how we read and interpret the primary text. It is seldom, however, that scholarly critics address this aspect of theatre and exactly how the choices made during the course of production refigure or enhance textual elements and impact the construction of meaning. In this paper I propose to examine this aspect of drama in three twenty-first century productions of Argentine plays: Eduardo Rovner's Lejana tierra mía (2002 production, written in 1992), Patricia Suárez's “La Varsovia," part of her trilogy, Las polacas (2002 production, written in 2001), and Griselda Gambaro's La señora Macbeth (2004 production, written in 2002). ${ }^{2}$ I will focus specifically on the deployment of scenic space as a generator of meaning and develop on the premises of Ubersfeld and McAuley, first, that the treatment of the stage space in any production represents a "mediation between different ways of reading the text" (Ubersfeld, Reading 110), and second, that "a different spatial organization produces different meanings" (McAuley 136).

Paradoxically, although theatre is a genre marked, indeed defined, by space, and one whose very being depends on space (the theatre building, 
the stage, the production's configuration of scenic and theatrical spaces, etc.), each of these plays focuses on places/spaces that are other than the ones depicted on stage - thus my title, "out of place." 3 Each revolves around other, invisible places evoked via the characters' words. How, then, does the concrete, visible composition of the setting (the mimetic space) affect our comprehension of the absent, invisible places (the diegetic spaces) on which the plays seem to focus? ${ }^{4}$ In addition, if we accept Ubersfeld's thesis that dramatic space functions as both metonymy and metaphor (Reading 100) and that the entire activity of staging a play consists in finding spatial equivalents for those rhetorical figures (109), exactly what do the configurations of space in these productions "say" to us, and how do they alter or supplement the text? ${ }^{5}$

In each work I will examine the spatial tropes on two levels: 1) those specified by the playwrights in the published texts, be they concrete, mimetic spaces (in the sense of scenic directions, specified settings) or diegetic (as revealed through the characters' words and gestures), and 2) those visible spatial elements not necessarily present in the text but rather introduced during the process of production. In juxtaposing these two levels, I wish to insist on the fact that the theatrical space of the production is constructed from or with the help of the text (Ubersfeld, Reading 103) even if the production team takes liberties with that text or defies it altogether. At times, of course, those liberties are a question of artistic vision or freedom. At others, the spatial elements added during the course of production are initially conceived in response to very specific (usually physical, architectural) constraints or exigencies. Nonetheless, I will argue that the solutions chosen during the processes of production of these plays enhanced textual elements and/or generated additional possible "reading(s)" of the plays, either of which may have been underdetermined without the performances' very specific treatments of space as trope, generator of meaning.

Although the three plays I have chosen are very different and written by dramatists with diverse styles and thematic preoccupations, what all three plays have in common is the fact that very little actually happens on stage. In each case, the significant action has already occurred or will occur elsewhere, off stage, in another place, while the "action" on stage is predominantly verbal. In this respect it is noteworthy that spatial confines not only reflect psychological confines but are also determining factors. In Lejana tierra mia, father and son talk about what was, the father's past, and what will or might be, the father's abandonment of the son to return to the Edenic space 
of his childhood. Similarly, in "La Varsovia," the two female characters talk about the places and lives they have left behind as well as those that await them in the future. While La señora Macbeth incorporates a somewhat larger cast of characters (five rather than two), the veritable action of the play still takes place elsewhere, in the world of the men, while the characters on stage do little but talk about it.

Of the stagings discussed here, the 2002 production of Rovner's Lejana tierra mia employed the most realistic setting. The play includes two characters, the father, a painter and dreamer, disillusioned with the dismal state of contemporary society and politics, and his pragmatic son, who assists him in his painting and is resigned, if not indifferent, to the problems of the world, convinced as he is that they cannot be corrected. ${ }^{6}$ During the course of the play, the two are painting a large mural (eventually named "Lejana tierra mía"), a depiction of the village of the father's childhood. As they work, the father bemoans the current sociopolitical situation in the world outside his studio and narrates (or invents) tales of the various characters who populated the idyllic world they are re-creating via the painting. In this way the play verbally juxtaposes two diametrically different worlds (the village of the past and the sociopolitical realities just outside the door), but it is telling that both spaces are exterior ones and ones that in turn contrast sharply with the interior space of the studio depicted on stage, a space that neither character leaves at any point. Interestingly, even the painting centers on exteriors as it portrays facades of buildings and the forest that surrounds them. In many ways, then, the father's artistic focus on exterior diegetic spaces enacts his desire to deal only in exteriors and surfaces: he will talk about distant times and exterior spaces but not about his emotions or his relationship with his son. In addition, unlike most traditional father-son plots in which the son leaves the home and reign of the father to seek his own experiences elsewhere, here it is the father who wishes to "forsake" the son to return to his remembered Eden. That is, he wishes to replace this place with another one, distanced in time and space, remembered and probably imaginary. ${ }^{7}$

Osvaldo Pellettieri has described the play as a deep reflection on both the possibility of establishing an authentic link with others and the impossibility as well as necessity of Utopia. ${ }^{8}$ Significantly, these themes are communicated precisely by means of this focus on other places/spaces and underscored by the organization of the scenic space. As indicated, while the two characters converse, they re-create, re-present the remembered spaces of the father's childhood, places that the son "knows" only as embodied in 
the father's words and painting, but ones which, as we shall learn, he too inventively (re)constructs. In this sense, the characters are literally and figuratively filling space, the blank spaces of the canvas and the metaphoric empty spaces of their silences and perhaps even lives. ${ }^{9}$ In order for the actors to face the audience and be heard by spectators as they were painting, the director opted for a transparent scrim to denote the canvas and placed it horizontally across center stage. ${ }^{10}$ Revealingly, the very location and material of the imagined painting underscored numerous thematic nuances. First, the audience was placed in a position of having to envision (metaphorically see) what was not there in fact (the painting) but only vaguely designated by the outline of the scrim, in much the same way as within the fiction, both father and son imagined (metaphorically saw) what was there only in artistic representation, the village that probably no longer exists (if it ever existed), that is now a memory, again a mere sketch or outline. Second, the fact that spectators could literally "see through" the painting/scrim encouraged us to do the same figuratively in regard to both the painting and the father's evocations: "see through" them, recognize them as chimeras, based perhaps on faulty memory or wishful thinking (longing for a better world, another space), as perhaps any artistic representation is, but chimeras that are surely essential to emotional survival.

This specific arrangement of the mimetic space encouraged a "reading" of the play that led to an emphasis on representation in general, be it that of the plastic arts or that of theatre, including this very production, as well as the spectator's role in interpreting/inventing in order to produce meaning. The foregrounding of this particular play or production as reproduction, art, was perhaps most apparent at the moments when the characters sat on the other side of the scrim, facing the audience. Although ostensibly studying the painting, the characters effectively mirrored the audience's position and activity, as we "studied" the performance. Even more revealing, a significant portion of the action took place on the other side of that scrim/painting, with the result that the audience watched the play (art) through the frame of art (the painting), in what called to mind the multiple layers of art and re-production that inform any dramatic performance. In the most literal sense, the staging reminded us, by means of the scrim, that not only do we invent, make something from nothing each time we view art, but also that we probably comprehend everything through the mediating filter of art of some sort. 
The literal blankness or emptiness of the painting/scrim also underscored the play's message about art in general. Although the father observes, "la pintura es una trampa para atrapar a la vida" (195) (as is, I would add, theatre), he later acknowledges, that art critics (and, I would add, theatre-goers) demand that art leave a testimony of its era because "están desesperados por el sinsentido de sus propias vidas" (198). Still, he acknowledges that he paints "porque no tengo la menor idea de qué sentido tiene todo" (198). Later, he insists that the only thing one can (and perhaps should) say about a work of art is "me emociona o no me emociona" (199). In this production, the blankness or emptiness of the scrim, the "work of art," reminds us not to look to art in general, or theatre in specific, to tell or show us anything. There is nothing there, in this case, quite literally. Art can only move us (emocionarnos) to re-member, re-create our own world, our own chimeras necessary for survival, and thus invent our "place" in the world.

At the beginning of the play, it would appear that the characters share little but the space of the studio, divergent as they are in all other aspects. At the end, however, the son argues that the father's proper place in the world is not there, in the remembered village, but here, in the studio with the son. What's more, we learn near the end that even the father's idyllic world as portrayed in the painting is partially the work of the son, who has added a number of elements of his own even though he has repeatedly prevaricated and assured the father that the latter had in fact painted them. As depicted in the play the father and the father's past are a creation of the son as much as vice versus. Carried over into theatrical terms, the play reminds us that the mediation of art works backward and forward: plays and their stagings are surely influenced by the text as well as by earlier works (i.e., mediated by art, seen through the literal and metaphoric scrim), but inversely the plays (and stagings) that we see today alter our interpretations not only of the text itself but also of what we have already seen and will surely affect how those earlier works will be staged in the future.

Although much of the dialogue of the play revolves around art and the evocation of other places, the division of the scenic space by the transparent scrim was particularly effective in accentuating, in very visual and physical ways, these motifs and demonstrating that the "other" spaces/places are here - wherever we are, they accompany us. As the son notes, "Mientras estemos acá [in the studio]... el pueblo existe" (222). Should the father leave the "here" to seek the "there," he will discover that the latter does not exist; it is as empty and imaginary as the painting/scrim. At the same time, the 
physical location of the scrim, which visually divided the stage in two, subtly underscored the numerous dichotomies on which the play is structured: here/ there, now/then, father/son, pragmatist/dreamer, city life/rural life, interior/ exterior, etc. In many ways, then, the scrim functioned as a visual metaphor for the graphic bar, the slash, that separates dichotomies (e.g., and/or) and often seems insurmountable. Although that slash would appear to suggest that "here" can never touch or overlap with "there," inside is detached from outside, the play underscores the interdependence and interrelation of the polarities. Insofar as each is defined by the other, the ostensible opposite, neither exists nor has meaning without and except as demarcated by the other (e.g., without a son there is no father, etc.). ${ }^{11}$ The fact that characters did walk around the painting to function on both sides of it not only signaled their ability to overcome that slash or barrier, but it also evoked the potential of art to envisage a world not crippled by polarities, by an "either-or" mentality, a world that might embrace the "and also." As depicted in Lejana tierra mia, "there" is also "here;" father is also son, and vice versa, metaphorically at least. ${ }^{12}$

The production of Patricia Suárez's "La Varsovia" was perhaps the least naturalistic of the stagings discussed here. This work is the final play in a trilogy, Las polacas, which centers on the activities of the Zwi Migdal, an organization that operated in Argentina during the early 1900s and imported impoverished adolescent girls, Eastern European Jews for the most part, by promising them marriage when in fact they were destined for brothels. ${ }^{13}$ "La Varsovia," which, according to the program, marks the third and final phase of the "business," takes place on a ship en route to Argentina and, as noted, comprises a series of interchanges between Hanna, the young Polish girl on her way to what she pretends to believe (and perhaps even does on some level) is marriage with Schlomo, and Ester, alias Mignón, an aging madam, who was earlier duped in the same manner and now assists Schlomo, the procurer, in his business of what is euphemistically, but relevantly, called pieles, hides. ${ }^{14}$

In a unique conceptualization of space, the 2002 production of the play at the Patio de Actores theatre filled Peter Brook's "empty space" (problematic though it may be) with other empty containers, buckets. Indeed, with the exception of being strewn with dozens of metal buckets, the scenic (mimetic) space was bereft of all elements of setting. Since no reference to these buckets appears in the published text, which specifies merely "Borda de un barco" (103), one must presume that they were the very effective 
brain child of the production staff and/or the director, Laura Yusem, noted for her creative stagings. ${ }^{15}$ This highly unconventional deployment of the mimetic space produced two interesting effects. First, since the buckets provided the only visual element (other than the two characters and the black walls of the scenic space), their importance in the production of meaning was impossible to ignore. At the same time, however, that meaning was necessarily open-ended (as were the buckets, quite literally) and polysemic, dependent as it was on the capacity (and willingness) of the individual spectator to construct it. ${ }^{16}$ Second, the hard, cold, metallic quality of the buckets provided a sharp contrast to the two female characters who, although somewhat psychologically "hardened" themselves, nonetheless appeared very vulnerable in contrast, unquestionably a statement on the defenselessness of the young women imported by the cold, vast organization, run like a welloiled machine, and brought to mind by those hard, metallic buckets.

There is undoubtedly any number of ways to "read" the buckets. On perhaps the most obvious level, since buckets often hold water, they functioned to evoke the sea and underscore the locus of the action, a ship in the middle of the Atlantic. At the same time, however, each individual bucket marked a very finite and limited space (that of the bucket itself). The contrast between the finite space of the individual bucket and the larger scenic space (which, because of its black walls gave the impression of being much more sizeable that it actually was) in turn replicated the characteristics of the place of the action - a limited space (the ship) within a vast one (the ocean). ${ }^{17}$ The scenic space (marked simultaneously as it was by the finite and the infinite) provided a further allusion to, on the one hand, the wide range of the organization's influences and, on the other, the limitations placed on its victims. At the same time, the juxtaposition of the finite and the infinite signaled those other places (diegetic spaces) remembered or imagined via the characters' words: the remembered Poland and space of the family home left behind, the imagined Argentina and place of their future "home." But, the buckets also served alternately as chairs, footwear, and even playing pieces in a game whose objective remained vague. This exceptionally unusual treatment of scenic space was disconcerting to say the least, but most effective in underscoring any number of thematic nuances. I will touch on just a few of them.

In their similarity and interchangeability, the buckets underscored the similarities of the "hides," the adolescent girls, being imported, and particularly the unexpected parallels between Mignón and Hanna. At the start of the play, Mignón, the older woman, more sophisticated and experienced, 
seems to be in a clear position of dominance. As the lights go up, the younger woman, Hanna, is retching, indication apparently of her discomfort with shipboard life and perhaps by implication with the life that awaits her in Argentina. ${ }^{18}$ Mignón is sure of herself, comfortable in her knowledge (which proves to be erroneous) of her relationship with Schlomo and the fact that, as his assistant, she shares some of the power of the master. As the one-act play ends, however, the two women have effectively changed places, not unlike the buckets that were frequently moved about on the stage. Now it is Mignón who retches, having learned that Hanna is indeed the "love" of Schlomo rather than she herself as she had believed. Furthermore, she has discovered that the latter is not only pregnant with Schlomo's child but from the beginning has been cognizant of the nature of the life to which she is being sent and aware as well of how to manipulate the situation to her best advantage (which, indeed, is not much of an advantage at all, but, for the moment at least, it is something more than what Mignón has). The sheer quantity of buckets and the manner in which they were moved around would also seem to suggest that just as the young Hanna is now replacing the more mature Mignón (who had earlier replaced a certain Bronia), at some future moment yet another new "bucket" or "hide" will come along, another, younger woman will replace Hanna, ad infinitum. In this sense, the seemingly endless repetition of the buckets brought to mind the endless repetition of history. ${ }^{19}$

On occasion the women inserted their feet into the buckets and walked in them, shuffling along, accompanied by the loud, grating sound the buckets made as they were dragged across the stage floor. While footwear often defines one, shoes (particularly fashionable women's shoes, and fashion is a major topic of the dialogue) also tend to limit one's freedom. While one can change shoes, as the characters changed buckets frequently, the fact or presence of the apparatus, the shoe, the bucket does not change. One's feet are still confined; one's mobility is still constrained. Thus, when used as footwear, the buckets materially signaled the less visible limitations and restrictions imposed on and suffered by these two women in specific as well as all others in similar positions. For these particular women, limited as they are by their socioeconomic positions, the restrictions are multiple. First, their families have sold them into the situations in which they find themselves because of their abject poverty, so that the rest of the family might survive. But, second, they are sold and are even more limited and restricted precisely because they are females in a patriarchal society, always at the mercy of a male, be it father, husband, procurer, or pimp. In addition, there can be little 
doubt that their ethnicity, the fact that they are Jewish, further restricts their freedom and movement in society.

When used as game pieces, shuffled and moved from place to place with no clear objective, the buckets signaled the clever, if indeed complex, game of power the two women are playing, with each other as well as with the larger, male-controlled society. Indeed, the women play something of a cat and mouse game in their attempts to outmaneuver each other, win favor with the master, and thereby derive, if only vicariously, some of his power, bask by association in the "glory" of his position. But, literally and figuratively, their game proves to be little more than rearranging buckets, ultimately changing nothing in the larger picture: the buckets, game pieces, can be moved but one cannot escape the macrostructure, and the "rules of the game" with its predetermined ending. As was the case with the buckets in their avatar as footwear, one can move but only within certain boundaries. One cannot escape.

But, the semiotic possibilities for the buckets do not end here. At moments a white liquid resembling milk was poured from one of them in what might be read as a reference to maternity, Hanna's pregnancy, which she believes will "buy her a ticket" out of the pending slavery. Clearly, she fails to recognize that maternity in her relation of inequality with Schlomo (and given his profession) will be just another form of slavery, if indeed she is even allowed to bring the pregnancy to term. Like the liquid that is merely transferred from one container to another, Hanna's pregnancy at best will merely "buy her a ticket" out of one bucket and into another, changing nothing. This metaphoric milk, combined with a tawny, grain-like substance that appeared to be wheat, which was poured from yet another bucket, might also bring to mind the image of the land of milk and honey (although it seemed to be a grain in this case rather than honey, both are nutritious foodstuffs and similar in color), the promised land, which in turn evokes both the ethnicity of the women and the fraud of promised lands in general. Just as the Jewish people were forced to leave their promised land, these women have been forced to leave Poland, although for them Poland is surely not the promised land: their poverty, ethnicity and gender prevent that land (and perhaps any space) from being a haven for them. Indeed, on any number of levels they are homeless outcasts, always en route to another promised land that never turns out to be quite what was promised, a factor accentuated by the bleak, essentially barren space of the stage. 
Last but not least, the buckets also provided an instrument for burying or hiding one's head (here in the bucket rather than in the proverbial sand) so that one could not, need not, see. At the end of the play, the crying Mignón stuck her head into one of the buckets, refusing in some sense to see and acknowledge her situation. Her gesture recalls a similar one on the part of the larger society that permitted the Zwi Migdal to operate for some 30 years and victimize what has been estimated at 3,000 girls or more..$^{20}$ It also recalls the psychological manipulation at work in a society that tolerates (perhaps even encourages) such exploitation. Although one of the victims of the "business in hides," Mignón justifies the exploitation and death of the martens, the animals that provide the skins and a transparent metaphor for the young women being victimized here: "Están en el mundo para ser usadas" (128), perhaps not unlike the buckets that populated the stage.

Griselda Gambaro's La señora Macbeth provides a complex reconsideration of Shakespeare's rendition of the Macbeth story. ${ }^{21}$ Here the female characters (Lady Macbeth and the witches) are positioned center stage throughout the play rather than in the peripheries much of the time (à la Shakespeare). ${ }^{22}$ The play encompasses a number of the themes and motifs that have come to be associated with Gambaro: Argentina's recent history (the disappeared and the "dirty war" of the 1970s and 1980s), issues of power and its abuse, the position of women in society, and the tendency of characters, male or female, to act as accomplices of the powerful in an effort to attain some shreds of their power and, hopefully, protect or save themselves. Here we find a Lady Macbeth who, while certainly not innocent, is portrayed in a role of far less malevolent agency than that assigned her by Shakespeare. Heredia has insightfully categorized her as a puppet rather than an instigator, an emotional and psychological cripple as much as an accomplice, and an incomplete being whose faults are more attributable to the loss of her own identity than to malice or ambition on her part (53). In addition, the play develops on the notion of Lady Macbeth as thoroughly immasculated, "taught to think as men, to identify with a male point of view, and to accept as normal and legitimate a male system of values" (Fetterley $\mathrm{xx}$ ). In many ways, her existence seems limited to serving as the reflection of himself that Macbeth requires. As one of the witches says to her, "El te dirá a su hora las palabras que quiere escuchar... Tu lengua será un espejo de su lengua" (35).

Just as the stage production of "La Varsovia" depended on elements not present in the published text, the configuration of the mimetic space in 
the production of La señora Macbeth, under the direction of Pompeyo Audivert, diverged significantly from the text, although, unlike Suárez, Gambaro did indeed include some fairly specific guidelines, none of which formed part of the 2004 staging. ${ }^{23}$ With the exception of a few chairs, the huge scenic space of the Sala Solidaridad of the Centro Cultural de la Cooperación was empty and very dimly lit, but its vastness definitively communicated a sense of the immensity and wide-spread range of the issues of power and its abuse that the play depicted. This was, quite literally, Peter Brook's "empty space," but it was an empty space that recalled the theory of Ngugi wa Thiong'o that what appear to be empty spaces are better defined as bare or open rather than empty since in reality they are filled, if indeed invisibly, with numerous physical, social, and psychic forces (13). Underscoring the importance of space and the contiguity of the local and global, the program described the setting of the action as "un rincón del tiempo y del espacio que es a la vez todos los espacios y los tiempos."

The most notable feature of the dimly lit scenic space was a ray of light that cut diagonally across the stage, into and out of which the characters moved. While presumably added by the production team, this ray of light, which split the scenic space as it cleaved the darkness, was particularly significant in the production of meaning and in underscoring many of the text's thematic concerns on a number of levels. First, in Shakespeare's Macbeth, as Barnet et al have observed, many scenes take place in darkness, but the final act, with the exception of the scene of Lady Macbeth's sleepwalking, takes place entirely in the light (xv). The same critics have interpreted this as a trope for the forces of good (light) replacing the forces of evil (darkness). Although I will argue that in the Gambaro play the ray of light and the darkness have far broader implications, the division of the scenic space here via that ray of light certainly suggested that forces of good and evil are necessarily co-existent, and that each character, insofar as s/he walks into and out of the light, partakes of both. Furthermore, the fact that this aspect of the lighting does not change during the course of the play negates the optimism proffered by Shakespeare (as interpreted by Barnet et al), suggesting that the evil will not be replaced by goodness just as the problems and power struggles depicted in the Gambaro play will not be resolved. Second, the ray of light paradoxically produced both a sense of vastness and one of narrowness or limitation. The poorly lit areas comprised the majority of the scenic space, while the very finite quality of the lighted strip of the stage made it seem even more restricted in relation to the rest of the space, 
suggesting that light (however we choose to interpret it metaphorically or metonymically) can make only limited, narrow inroads into those of darkness, which is far more widespread.

That ray of light further functioned as something of an arrow that continually drew spectators' attention to the elsewhere, the offstage diegetic places where the centers of power resided but which we, like Lady Macbeth, could neither see nor influence. Revealingly, all the important actions of the play happen elsewhere, in the public world of males and politics, in the world to which Lady Macbeth has access only vicariously, only as Macbeth's lackey. By pointing to that other space, that other world, the ray of light also reminded us of the influence, indeed domination, of the public, political, and implicitly "masculine" spaces on the private realm of the women depicted on stage. Although all we witness are the women's conversations, those conversations suggestively focus on that other space: the events and politics of the world that have happened, are happening, and will happen, events that affect the females in so many ways, but over which they have little control, events that for them and for the audience remain in the dark, and events that they, like the audience, can only attempt to imagine and understand. Although the witches, via their prophecies, do affect those events off stage to some degree, the fact that the prophecies are dependent on interpretation precludes the possibility of control. Like playwrights and directors, the witches provide the enigmatic words but cannot regulate how they will be received and interpreted by their audiences.

In this respect, the contrast between the diagonal ray of light and the vast shadowy space on either side of it evoked the questions of truth and appearances, knowledge (what we can see, understand, know) and ignorance (the mystery of the metaphoric darkness), along with the difficulty of ever really seeing or understanding anything. ${ }^{24}$ The darkness of the majority of the scenic space would thus seem to be a reference to the vastness of what we cannot know, master, and, by extension, control, all that information that the powerful would keep from us, all that does not fit neatly into the narrow conceptions of truth and knowledge promulgated by our master narratives be they political, philosophical, social, etc. Although, as noted, the audience is never provided direct access to the important actions happening off stage, even on stage much of the action took place outside of that ray of light. As a result, it was often difficult to see the actresses clearly, to be sure what they were doing. As they stepped into the ray of light, for a moment or two we could see clearly, but then they disappeared into the shadows again, almost 
as invisible to us as the off-stage action. Surely, Lady Macbeth's position in relation to the diegetic masculinist spaces was similar to our relation to the darken spaces on stage. Throughout the play she and the witches talk about understanding another's actions or words (which were seldom consistent) and throughout she seems have occasional insights, but she inevitably returns to the darkness (in all its connotations here), reminding us of the fact that we depend on the words of others to comprehend the world that surrounds us but that those words are not necessarily reliable, motivated and limited as they often are by vested interests and by our inability to interpret with any significant degree of validity. This oscillation between knowledge and ignorance, recognition and misrecognition, is perhaps nowhere more apparent than in Macbeth's (off-stage) misreading of the witches' prophecies. When resemanticized, recontextualized here, that misinterpretation of the prophecies seems to be a direct comment on recent historical events in Argentina and the ability of politicians to manipulate meaning and knowledge as they keep us in the metaphoric darkness. ${ }^{25}$

This potential for misinterpreting the prophecies (or anything) is obliquely evoked in Lady Macbeth's words early in the play. There Lady Macbeth maintains that the watchdogs should guard the palace "con gruñidos mansos, con miradas dulces, mostrando los dientes sin morder jamás" (16), that is, to be ferocious but not appear to be, to juxtapose the figurative light and darkness, sweetness and cruelty, so that it is impossible to discern between them. As this was enacted and made visible on stage, in the juxtaposition of the light and shadows in the scenic space, we were reminded that when we find ourselves in a place with either too much or too little light, with time our eyes will adjust and allow us to perceive what is there. The fact that the light and darkness were juxtaposed in this production effectively prevented our eyes from ever adjusting so that we might perceive clearly, thus confusing the issues for us just as the dogs' gentle growls might. ${ }^{26}$

The deployment of the theatrical space (as opposed to the scenic space) was also particularly evocative in this production. The scenic space was at floor level, and on one side stadium-type seating rose above it. Thus, spectators were located on a physically higher level, looking down on the action, literally and figuratively. In spite of our panoptic position (above that action, ostensibly in a position to dominate the scenic space below), we still could not master the events, in part due to the lighting as discussed and in part because the important action was occurring elsewhere. In yet another powerful image, the configuration of the audience space in relation to the 
scenic space brought to mind a sports arena, an apt trope for the patently masculinist world that Lady Macbeth inhabits insofar as it marks a space for playing games, games that establish winners and losers, those that overpower and those that are overpowered, games that theorists have posited often reflect life, and games that are often played as if they were a question of life and death. ${ }^{27}$ Clearly, all the metaphoric games played in both the mimetic and the diegetic spaces here are a question of life and death, but again the most deadly ones have occurred, will occur, or are occurring outside the arena to which we have been afforded very limited access.

On a final note, and continuing this notion of our panoptic position that still does not let us see what we perhaps most need to see, the production relied on yet another very interesting and eloquent use of space. When the ghost of Banquo appeared to Lady Macbeth in Scene 4, he appeared from within the audience. Although we had not noticed him (in part because he was among us - too close to us for us to perceive him - and in part because the space he shared with us was darkened), he had apparently been there all along. Victim of Macbeth, one of the many losers in the latter's political games, Banquo sat among us; he was one of us, in what provided a chilling commentary on our own position in the world and evoked the potential for any of us to lose this game whose rules we perhaps never really quite grasp.

In conclusion, then, while none of the stagings distorted the plays or deviated from the published dialogues, the choices made in the configurations of the theatrical spaces surely underscored certain elements of the texts and thus directly affected audience reception and comprehension of both the performances and the play texts. At the same time all three stagings underscored "the centrality of the spatial function in the production of meaning" (McAuley 32). Furthermore, I would posit that the deployment of scenic space in each of these three plays developed on the postmodern notion of the importance and relativity of space/place/location as well as the impossibility of knowing or communicating any absolute truth, that is, any "truth" that is not subjective, created, vested, and contingent - dependent on the literal and figurative locations of both its producers and receivers. In sum, then, as these productions have demonstrated, space, literal and figurative, metaphoric and metonymic, is far more important in theatre than we have often acknowledged and certainly too seldom afforded the serious critical attention it deserves. 


\section{Notes}

1 Similarly, Ubersfeld has proposed that although the text suggests "a certain stage locus with concrete determinations and coordinates," it is easy to disregard, subvert, or ignore those indications (Reading 106).

2 Lejana tierra mia debuted in 1992 in the Teatro Regio in Buenos Aires and was published in 1994. I base my analysis here on the 2002 production at the Teatro Andamio ' 90 (Buenos Aires), directed by Oscar Barney Finn, which I saw in August of 2003.

Las polacas comprises three plays, "Historias tártaras," "Casamentera" and "La Varsovia." The latter is the focus of my analysis here. The three plays debuted as a unit in the Patio de Actores theatre in Buenos Aires in June of 2002. Each play had different actors and a different director. "La Varsovia" was directed by Laura Yusem (who has also directed a number of Gambaro plays). I saw the production in August of 2003.

La señora Macbeth was published in 2003 and debuted in April of 2004 in the Sala Solidaridad of the Centro Cultural de la Cooperación in Buenos Aires. It starred the highly respected actress, Cristina Banegas, and was directed by Pompeyo Audivert. I saw the production in August of that year. The play was later moved to the Teatro Cervantes, one of the major theatres in Buenos Aires and one that is government supported. Although still directed by Audivert, there were apparently major changes in the production when it opened in its new venue.

3 I follow the lead of Ubersfeld here in distinguishing between scenic space (the space of the actors) and theatrical space (the space of both actors and spectators) (Diccionario 48).

4 Michael Issacharoff distinguishes between mimetic space (that represented on stage, seen by the audience) and diegetic space (that not represented but only imagined by the audience), conveyed via the words of the characters (cited in McAuley). Hanna Scolnicov's distinction between "space within" (i.e. that which is visible on stage) and "space without" (that which we do not see) is also useful (cited in McAuley).

5 In her Diccionario Ubersfeld defines dramatic space (espacio dramático) as an abstraction that includes not just the representational signs but also all the virtual spatiality of the text, including what is considered extra-spatial (48, my translation).

6 Mogliani reads the generational conflict in terms of the recent events of Argentine history - the devaluation of the peso and the economic crash of December 2001 - and the squashed idealism of those of the father's generation.

7 Again, see Mogliani for a somewhat different reading of the play.

8 See the back cover of the published text.

9 Interestingly, there is a subtle suggestion that this emptiness might be related to the absence of the wife/mother who has died and to whose demise the characters refer on occasion.

${ }^{10}$ Although in my conversations with him, Rovner attributed the choice of the transparent scrim to the director, Oscar Barney Finn, the stage directions of the published text offer the possibility that the mural the two men are painting "también puede no estar, en cuyo caso la opción sería que esté el marco del mural y los personajes 'mimando' la acción" (185).

"The human being may exist, but his role and designation as father does not.

12 At one point the son admits, as the father earlier had, " $i$ No tengo la menor idea de para qué vivo, ni del sentido de mi vida [. . .]!" (220). Interestingly, he concludes his tirade with, "Pero, pará... ¿Vos sois mi viejo o mi hijo?"

${ }^{13}$ See the Glickman study for an overview of the organization and its denunciation by Raquel Liberman.

${ }^{14}$ The first play of the trilogy, "Historias tártaras," takes place on a train in Europe and deals with the procurer Schlomo who is en route to "buy" a bride. The second, "Casamentera" 
(re-named "La señora Golde" in the production), focuses on the negotiations between Schlomo and the local agent, Golde. Thus, in many ways the three plays pinpoint the three major steps in the procurement of these young women.

is Interestingly, in her discussion of stage objects McAuley has noted that in contemporary theatre " $[\mathrm{w}] \mathrm{hen}$ the presentational space no longer has to create a credible image of a fictional place [. . .] when the illusion of being somewhere other than the theatre is no longer a central requirement, then the object is liberated to fulfill multiple expressive functions. The object, being physically present in the space, necessarily serves to shape and define that space and, equally necessarily, has an impact upon the human users of the space" (173).

${ }^{16}$ Indeed, not all spectators were willing to find or construct meaning. A number of people commented to me that they just found the production (and probably by association, the play text) absurd.

17 In reality, the scenic space of the theatre was very small, but the black walls were effective in making the edges seem to disappear, so it gave the impression of being spacious in spite of its compact size.

${ }^{18}$ I say "apparently" because this is our initial impression. Later, in retrospect, we realize that the nausea was probably related to her pregnancy.

19 Surely, too, this repetition of history would lead the Argentine audience to recall the atrocities of their more recent history, the military dictatorship and the "dirty war" of the 1970 s and 1980s.

${ }^{20}$ Suárez gives the figure of 3,000 in the program and on the back cover of the published edition. Glickman gives 30,000 as the number of women employed in Zwi Migdal's 2,000 brothels in 1929 (7).

${ }^{21}$ It is generally accepted that Shakespeare's play is based loosely on historical events of the eleventh century, chronicled in Raphael Holinshed's Chronicles of England, Scotland, and Ireland (1577), with which he took significant liberties.

22 Although the play is titled La señora Macbeth, the character is named Lady Macbeth.

${ }^{23}$ For example, at the start of Scene 1 the stage directions specify, "Un enorme objeto en madera basta, que es una especie de escultura barroca. Figura un trono y la misma construcción lleva adosados un juego de hamacas, un tobogán" (15).

${ }^{24}$ Persino observes, "cuando un personaje sale de ese espacio iluminado se sugiere la entrada en el vacío, en la nada, de la cual hay que regresar" (129).

${ }_{25}$ Although Argentina and the "dirty war" are never mentioned, they unquestionably provide another implicit diegetic space evoked in the mind of the Argentine spectator. Heredia obliquely alludes to this unarticulated referent: "La miserable intimidad de los excesos del poder contemplada desde sus silenciosos cómplices [ . . .] resulta siempre un tópico incómodo para una sociedad que aún padece las culpas de su histórica aquiescencia" (52)

${ }^{26}$ This notion of cruelty disguised as or juxtaposed with benevolence or sweetness is a frequent motif in Gambaro's work.

${ }^{27}$ I think quite specifically here of Argentina's passion for soccer.

\section{Works Cited}

Barnet, Sylvan, Morton Berman, and William Burto, eds. Classic Theatre: The Humanities in Drama. New York: Little, Brown, 1975.

Fetterley, Judith. The Resisting Reader: A Feminist Approach to American Fiction. Bloomington: Indiana UP, 1978. 
Gambaro, Griselda. La señora Macbeth. Teatro. Buenos Aires: Norma, 2003.

Glickman, Nora. The Jewish White Slave Trade and the Untold Story of Raquel Liberman. New York: Garland, 2000.

Heredia, María Florencia. "La señora Macbeth: Detrás de un tirano..., o la contracara del poder." Teatro XXI 10.19 (Spring 2004): 52-53.

Heuvel, Michael Vanden. Performing Drama / Dramatizing Performance. Ann Arbor: U of Michigan P, 1993.

Issacharoff, Michael. Discourse as Performance. Stanford: Stanford UP, 1989.

McAuley, Gay. Space in Performance: Making Meaning in the Theatre. Ann Arbor: U of Michigan P, 1999.

Mogliani, Laura. "Lejana tierra mía: La revalorización del prójimo." Teatro XXI 7.15 (Spring 2002): 55-56.

Ngugi wa Thiong'o. "Enactments of Power: The Politics of Performance Space." The Drama Review 41.3 (Autumn 1997), 11-30.

Persino, María Silvina. "Contra la corriente: Teatro en Buenos Aires, invierno 2004." Latin American Theatre Review 38.2 (Spring 2005): 123-33.

Rovner, Eduardo. Lejana tierra mía. Teatro 1. Buenos Aires: Ediciones de la Flor, 1994. 183-223.

Scolnicov, Hanna. Woman's Theatrical Space. Cambridge: Cambridge UP, 1994.

Suárez, Patricia. "La Varsovia." Las polacas. Buenos Aires: Ediciones Teatro Vivo, 2002. 102-138.

Ubersfeld, Anne. Diccionario de términos claves del análisis teatral. Buenos Aires: Galerna, 2002.

. Reading Theatre. Trans. Frank Collins. Toronto: U of Toronto P, 1999. Trans. of Lire le théâtre I. 1996. 